\title{
Effect of Concentration on the Optical and Solid State Properties of ZnO Thin Films Deposited by Aqueous Chemical Growth (ACG) Method
}

\author{
S. L. Mammah ${ }^{1,2}$, F. E. Opara' ${ }^{2}$ F. B. Sigalo², S. C. Ezugwu ${ }^{3}$, F. I. Ezema ${ }^{3}$ \\ ${ }^{1}$ Department of Science Laboratory Technology, School of Applied Sciences, \\ Rivers State Polytechnic, Bori, Nigeria \\ ${ }^{2}$ Department of Physics, Faculty of Science, Rivers State University of Science and Technology, \\ Port Harcourt, Nigeria \\ ${ }^{3}$ Department of Physics and Astronomy, University of Nigeria, Nsukka, Nigeria \\ Email: sylvestermammah@yahoo.com,erfopara2002@yahoo.com, fiezema@yahoo.com, sabroze@yahoo.com
}

Received July 11, 2012; revised August 15, 2012; accepted August 24, 2012

\begin{abstract}
Thin films of Zinc Oxide ( $\mathrm{ZnO})$ having different concentrations were deposited using the Aqueous Chemical Growth (ACG) method. The films were characterized using Rutherford Back Scattering (RBS) spectroscopy for chemical composition and thickness, X-Ray Diffraction (XRD) for crystallographic structure, a UV-VIS spectrophotometer for the analysis of the optical and solid state properties which include spectral absorbance, transmittance, reflectance, refractive index, direct band gap, real and imaginary dielectric constants, absorption and extinction coefficients and a photomicroscope for photomicrographs. The average deposited film thickness was $100 \mathrm{~nm}$. The results indicate that the values of all the optical and solid state properties investigated vary directly with concentration except transmittance which is the reverse. Thus, the optical and solid state properties of $\mathrm{ZnO}$ thin film deposited by the Acqueous Chemical Growth method can be tuned by deliberately controlling the concentration of the precursors for various optoelectronic applications including its application as absorber layer in solar cells.
\end{abstract}

Keywords: Component; Formatting; Style; Styling; Insert

\section{Introduction}

Zinc Oxide is an amphoteric oxide which exists in the form of white powder (zinc white) at room temperature [1]. Though zinc oxide exists naturally in the earth crust (zincite), it is the synthetic $\mathrm{ZnO}$ produced in laboratories that are usually used in industries [2].

Crystalline zinc oxide is thermochromic [3]. Apart from the ability of $\mathrm{ZnO}$ to react with acids, it also reacts with bases to produce soluble zincates [4-6]. Zinc oxide has high stability at room temperature and decomposes into zinc vapour and oxygen at about $1975^{\circ} \mathrm{C}$ [7]. Though zinc oxide can exist in either of hexagonal wurtzite, cubic zinc blende and cubic (rock salt) structure, the hexagonal wurtzite structure is the most common at room temperature. The different polymorphs of $\mathrm{ZnO}$ do not possess the property of symmetry inversion. This and other properties such as ionic bonding account for the strong piezoelectricity of both hexagonal and zinc blende $\mathrm{ZnO}$ $[8,9]$.

The hexagonal wurtzite structure has the point group 6 $\mathrm{mm}$ (Hermann-Mauguin notation) or $\mathrm{C}_{6 \mathrm{v}}$ (schoenflies notation) and a space group of $\mathrm{P}_{3}$ me or $\mathrm{C}_{6 \mathrm{v}}^{4}$. Its lattice constants are $\mathrm{a}=3.25 \AA$ and $\mathrm{C}=5.2 \AA[10]$.

The many applications to which $\mathrm{ZnO}$ can be put has made it to be a material for constant scientific study. The diverse applications of $\mathrm{ZnO}$ are derived from its unique properties which include non-toxicity, good electrical conductivity, high luminous transmittance, good substrate adherence, good optical behaviour and stability in plasma atmosphere [11,12].

$\mathrm{ZnO}$ has been tested and found to behave as a semiconductor having a wide bulk direct band gap of about $3.37 \mathrm{ev}$ at room temperature [13] $\mathrm{ZnO}$ has been used for the fabrication of light emitting diodes, varistors, photo detectors, piezoelectric cantilever, gas sensors, buffer layer in solar cells and in photonic crystals [14-21].

As a result of the strategic importance of $\mathrm{ZnO}$ to humanity, various deposition methods have been used for its production in the form of thin films. Among these methods are the chemical bath deposition (CBD) [22-26].

Successive Ionic Layer Adsorption and Reaction (SILAR) method [27,28]. 
Spray pyrolysis method [29].

Electro deposition method [30,31].

The ACG method is a novel method for the deposition of $\mathrm{ZnO}$ thin films; hence the literature on it is sparse.

Indeed F. I. Ezema (2004) [26] reported that "Thin films of $\mathrm{ZnO}$ have been used but its preparation techniques have been restricted to sputtering, vacuum evaporation, chemical vapour deposition, spray prolysis, molecular beam epitaxy, sol gel and pulse laser".

Among the advantages which the ACG method have over the other methods are simplicity, low cost, reproducibility, availability of materials, environmental friendliness (non toxicity of residue), non requirement of surfactant, templates and complexing agents, low temperature requirements, ability to produce nanostructures, high purity (absence of surfactants), suitability for large scale production etc. [32,33].

This paper reports the effect of concentration of precursors on the optical and solid state properties of $\mathrm{ZnO}$ thin films deposited using the ACG method with $\mathrm{Zn}\left(\mathrm{NO}_{3}\right)_{2}$ $6 \mathrm{H}_{2} \mathrm{O}$ as precursor material. The spectral analysis of the optical and solid state properties was carried out using a Unico UV-2102 PC spectrophotometer.

\section{Experimental Details}

$\mathrm{ZnO}$ thin films were deposited on clean glass slides using Aqueous Chemical Growth method.

Equimolar concentrations of hydrated zinc nitrate

$\left(\mathrm{Zn}\left(\mathrm{NO}_{3}\right)_{2} \cdot 6 \mathrm{H}_{2} \mathrm{O}\right)$ and hexamine in $80 \mathrm{ml}$ of water were used as precursors.

Hexamine was used to make the zinc nitrate alkaline. Three samples having different concentrations of the precursors were prepared as shown in Table 1 below.

Masses of samples were measured using an analytical microbalance. The masses of the components of each sample were put into a $100 \mathrm{ml}$ pyrex bottle together with 80 $\mathrm{ml}$ of water. The contents were properly mixed using a magnetic stirrer.

The pyrex bottles were then tightly corked and care fully placed in an oven at a temperature of $90.00^{\circ} \mathrm{C}$.

The average deposition time for the films was twelve hours.

The chemical reactions which resulted in the crystallization of $\mathrm{ZnO}$ are:

$$
\begin{aligned}
& \mathrm{C}_{6} \mathrm{H}_{12} \mathrm{~N}_{4}+6 \mathrm{H}_{2} \mathrm{O} \rightarrow 6 \mathrm{HCHO}+4 \mathrm{NH}_{3} \\
& \mathrm{NH}_{3}+\mathrm{H}_{2} \mathrm{O} \rightarrow \mathrm{NH}_{4}^{+}+\mathrm{OH}^{-} \\
& 2 \mathrm{OH}^{-}+\mathrm{Zn}^{2+} \rightarrow \mathrm{ZnO}+\mathrm{H}_{2} \mathrm{O}[34]
\end{aligned}
$$

\section{Results and Discussion}

The elemental composition of sample $\mathrm{C}_{2}$ was analyzed using Rutherford Backscattering (RBS).

The result is as shown in Figure 1. Judging from the film composition shown in the Table 2 below, we conclude that the elements contained in sample $\mathrm{C}_{2}$ are $\mathrm{Zn}$ $(0.050)$ and oxygen (0.950) while the glass substrate has the composition $\mathrm{O}(0.500), \mathrm{Si}(0.120), \mathrm{Ca}(0.100), \mathrm{Al}$ $(0.100)$ and $\mathrm{Na}(0.180)$. This is summarized in Table 2. The thickness of the film is given as $100 \mathrm{~nm}$.

The X-Ray diffractogram of the ACG $\mathrm{ZnO}$ thin films were studied to determine its crystalline nature.

The thin films were scanned continuously between 0 and 70 at step size of 0.03 and at time per step of $0.15 \mathrm{~s}$. The Figure 2 below shows the intensity of peaks versus diffraction angle $2 \theta$ for sample $\mathrm{C}_{2} \mathrm{ZnO}$ thin film using $\mathrm{CuK}_{\alpha}$ radiation source having a wavelength of $1.54056 \AA$. The X-ray diffractogram reveal several peaks corresponding to directions of strong reflections. Some of the observed peaks are $30.00^{\circ}, 32.50^{\circ}, 34.42^{\circ}, 45.56^{\circ}$ and $54.87^{\circ}$, and $67.50^{\circ}$.

The $34.42^{\circ}$ agree with the preferred orientation along the (002) plane reported by Ajuba et al. (2010) [35] and Shinde et al. (2005) [36] who used the CBD and SILAR methods respectively. Also, the $67.50^{\circ}$ fairly agree with the (112) plane reported by Ajuba et al. (2010) [35,36].

The diffractogram reveal sharp diffraction peaks which is indicative of good crystallinity [37-41].

Table 1. Three samples of different concentrations of the precursor.

\begin{tabular}{cccccc}
\hline Sample of mass & $\mathrm{Zn}\left(\mathrm{NO}_{3}\right)_{2} \cdot 6 \mathrm{H}_{2} \mathrm{O}$ & Mass of Hexane & Conc. of $\mathrm{Zn}\left(\mathrm{NO}_{3}\right)_{2} \cdot 6 \mathrm{H}_{2} \mathrm{O}$ & Conc. of Hexane & Volume of $\mathrm{H}_{2} \mathrm{O}$ \\
\hline $\mathrm{C}_{3}$ & $0.60 \mathrm{~g}$ & $0.030 \mathrm{~g}$ & $0.025 \mathrm{M}$ & $0.025 \mathrm{M}$ & $80.00 \mathrm{ml}$ \\
$\mathrm{C}_{4}$ & $1.20 \mathrm{~g}$ & $0.060 \mathrm{~g}$ & $0.050 \mathrm{M}$ & $0.050 \mathrm{M}$ & $80.00 \mathrm{ml}$ \\
$\mathrm{C}_{2}$ & $2.40 \mathrm{~g}$ & $0.112 \mathrm{~g}$ & $0.100 \mathrm{M}$ & $0.100 \mathrm{M}$ & $80.00 \mathrm{ml}$ \\
\hline
\end{tabular}

Table 2. Elemental composition of ZnO thin film and substrate from RBS analysis.

\begin{tabular}{ccccccc}
\hline & Oxygen & Zinc & Silicon & Calcium & Aluminium & Sodium \\
\hline ZnO thin film & 0.950 & 0.050 & - & - & - & - \\
Glass substrate & 0.500 & - & 0.120 & 0.100 & 0.100 & 0.180 \\
\hline
\end{tabular}




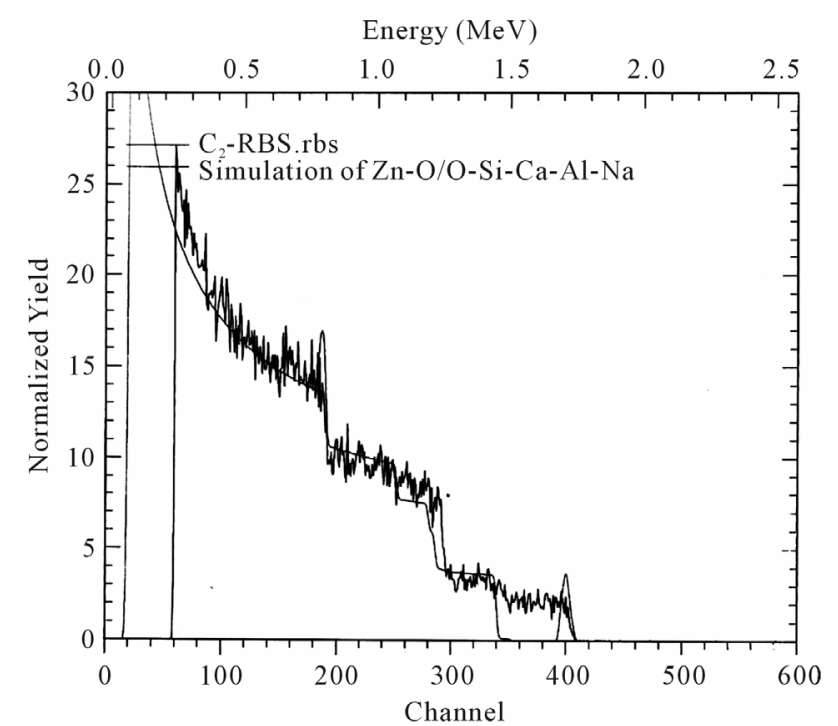

Figure 1. RBS analysis for ACG ZnO thin film (sample $\mathrm{C}_{2}$ ).

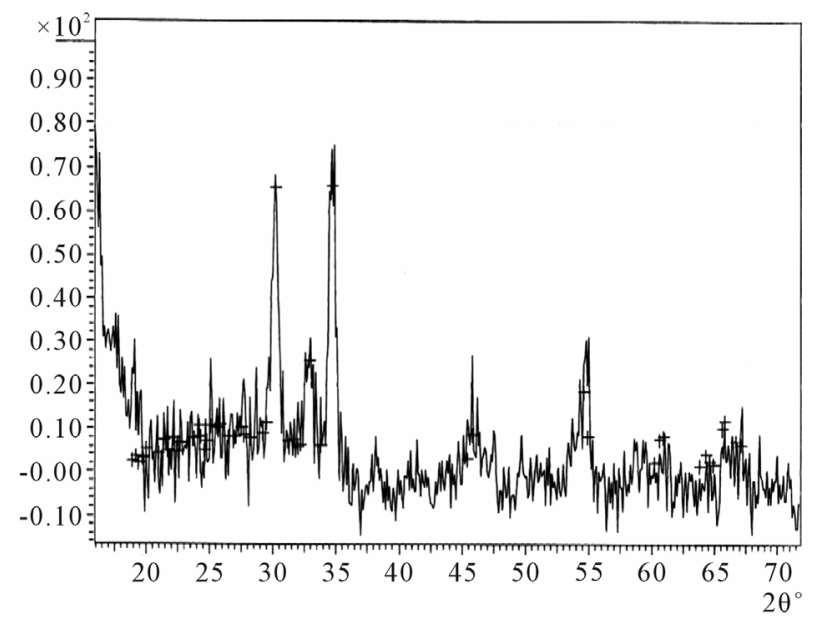

Figure 2. X-Ray diffractogram for ACG ZnO thin film (sample $\mathrm{C}_{2}$ ).

The XRD pattern shows that film is crystallized in the wurtzite $\mathrm{ZnO}$ hexagonal P6(3) mc structure. (JCPDF CARD no. 36-1451) [42].

The mean size of the crystallite was estimated to be 12 nm using the Sherrer formula which is given as:

$$
D=\frac{K \lambda}{\beta \cos \theta}
$$

where $K=0.9$

$\lambda=1.541 \AA$ is the diffraction peak angle $\left(34.42^{\circ}\right)$ and $\beta$ is the Full Width at Half Maximum (FWHM) corresponding to the diffraction peak.

The spectral absorbance of films is as shown in Figure 3.

The $0.05 \mathrm{M}$ concentration has an average absorbance value of 0.28 in the visible region while the $0.025 \mathrm{M}$ concentration has an average absorbance value of 0.268 in the visible region.

However, the $0.05 \mathrm{M}$ concentration has the lowest absorbance value of 0.21 in the infrared region.

Absorption peaks clearly occurred in film $\mathrm{C}_{2}$ at 368 $\mathrm{nm}, 496 \mathrm{~nm}$ and $656 \mathrm{~nm}$ but were not so clearly defined in films $\mathrm{C}_{3}$ and $\mathrm{C}_{4}$. Ezema [26] reported absorption peaks at $3.68 \mathrm{~nm}, 449 \mathrm{~nm}$ and $566 \mathrm{~nm}$ using Chemical Bath Method. The difference in the absorption peaks may be due to deposition method. The spectral transmittance of the films is as shown in Figure 4. Transmittance decreases with concentration in the visible region. The $0.1 \mathrm{M}, 0.05$ $\mathrm{M}$ and $0.025 \mathrm{M}$ concentrations has average transmittance of $45.5 \%, 53.2 \%$ and $54.60 \%$ respectively in the visible region.

However, the $0.05 \mathrm{M}$ concentration has the highest transmittance of about $61.8 \%$ in the ultraviolet region. The transmittance of the films in the visible region is generally lower than the above $85 \%$ transmittance reported using Chemical Bath Deposition method [43].

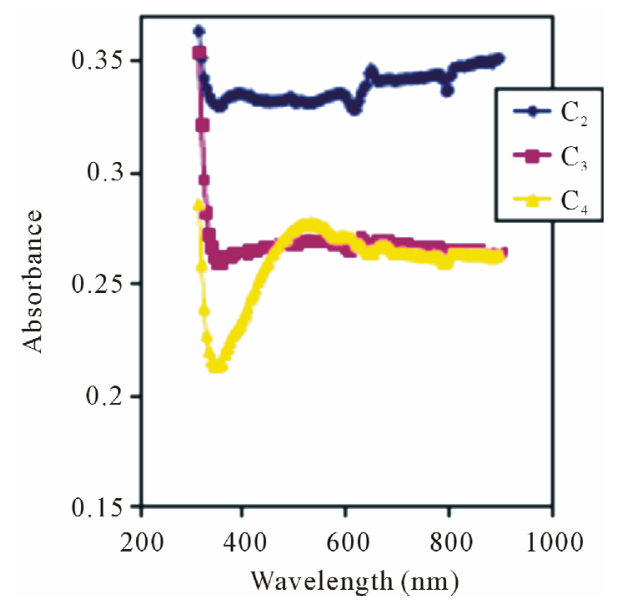

Figure 3. Absorbance vs. wavelength for $\mathrm{ZnO}$ thin film at different conc.

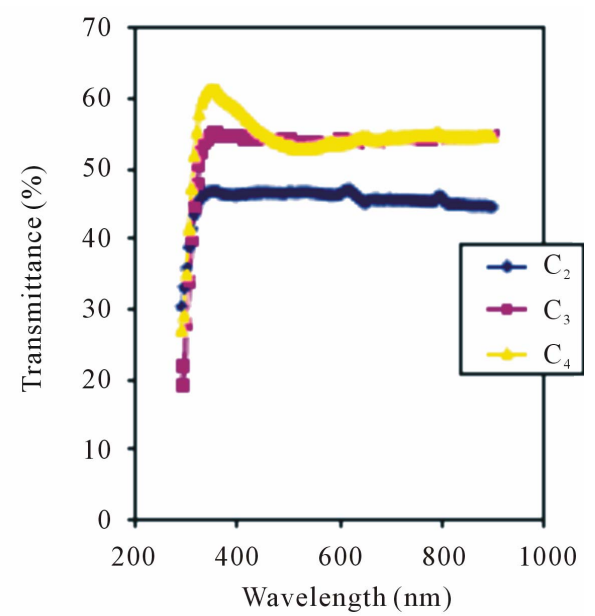

Figure 4. Transmittance vs. wavelength for $\mathrm{ZnO}$ thin films at different conc. 
It is also much lower than the $90 \% 95 \%$ transmittance in the UV-VIS-NIR regions for $\mathrm{ZnO}$ thin films deposited using spray pyrolysis method [44,45] and Sol Gel method [46].

It has been reported that the transmittance of a film increases as its thickness decreases [26].

The average thickness of the films being reported on is $100 \mathrm{~nm}$ which is far smaller than the $0.203 \mu \mathrm{m}$ and 0.069 $\mu \mathrm{m}$ thicknesses which gave average transmittances of $62 \%$ and $75 \%$ respectively that has been reported [26]. Thus, the transmittance of films deposited by ACG method are relatively lower compared to the ones deposited by other methods even though the thicknesses are smaller. The spectral reflectance of the films being reported on is as shown in Figure 5. Reflectance increases with concentration in the visible region.

The $0.1 \mathrm{M}, 0.050 \mathrm{M}$ and $0.025 \mathrm{M}$ concentrations reflect an average of $20.25 \%, 19.38 \%$ and $18.88 \%$ of visible electromagnetic waves. These values are higher than the average of $12 \%$ to $17 \%$ reflectance of films deposited using Chemical Bath Method as reported by Ezema [26].

Thus, films deposited by ACG method are better reflectors than those deposited by Chemical Bath Method. Absorption coefficient increases with concentration in the visible region as shown in Figure 6.

The average absorption coefficients for the $0.025 \mathrm{M}$, $0.05 \mathrm{M}$ and $0.1 \mathrm{M}$ concentrations are $0.62,0.65$ and 0.77 respectively. However, in the UV region, $0.05 \mathrm{M}$ has the lowest absorption coefficient of about 0.49 .

Refractive index is fairly constant in the visible region as shown in Figure 7. The $0.1 \mathrm{M}, 0.05 \mathrm{M}$ and $0.025 \mathrm{M}$ concentrations have average refractive indices of 2.3, 2.225 and 2.2 respectively. However, the $0.05 \mathrm{M}$ concentration has the lowest refractive index of about 2.05 in the UV region.

It has been reported that the refractive index of $\mathrm{ZnO}$ films doped with Li deposited by spray pyrolysis lie between 1.60 and 2.20 at a wavelength of $500 \mathrm{~nm}$ [45], while Ezema [26] gave the average refractive index of the $\mathrm{ZnO}$ films deposited by Chemical Bath method as being between 1.64 and 1.98 and also reported observed peak values of 2.28 at $368 \mathrm{~nm}$ and 1.72 at $569 \mathrm{~nm}$. In our own case, the refractive indices for the different concentrations were generally uniform in the visible region.

Extinction coefficient decreases with concentration and also decreases with increasing photon energy (wavelength) in the visible region as shown in Figure 8. The value of extinction coefficient for $0.1 \mathrm{M}$ concentration ranges from $37.85 \times 10^{-3}$ for $2 \mathrm{eV}$ to $27.14 \times 10^{-3}$ for 3 $\mathrm{eV}$ in the visible region. Similarly, the values of extinction coefficient for $0.05 \mathrm{M}$ concentration ranges from $35 \times$ $10^{-3}$ for $2 \mathrm{eV}$ to $19.64 \times 10^{-3}$ for $3 \mathrm{eV}$ and that of the $0.025 \mathrm{M}$ concentration ranges from $30 \times 10^{-3}$ to about $21.43 \times 10^{-3}$ at $3 \mathrm{eV}$ in the visible region.

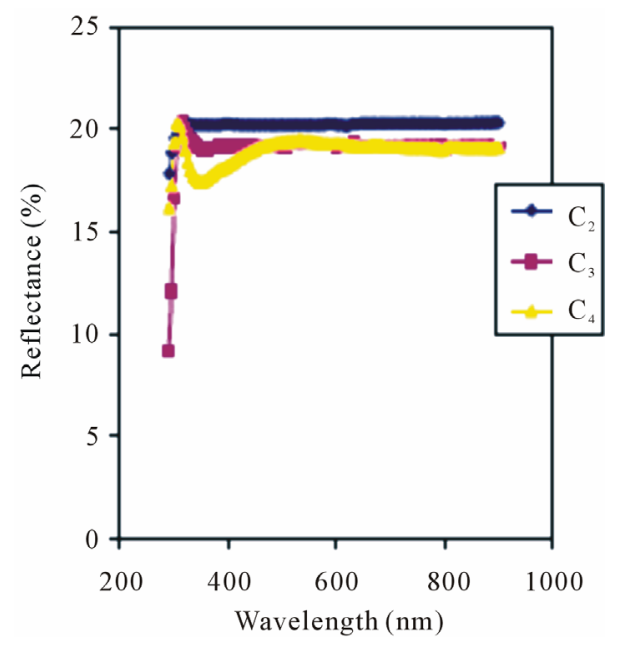

Figure 5. Reflectance vs. wavelength for $\mathrm{ZnO}$ thin films at different conc.

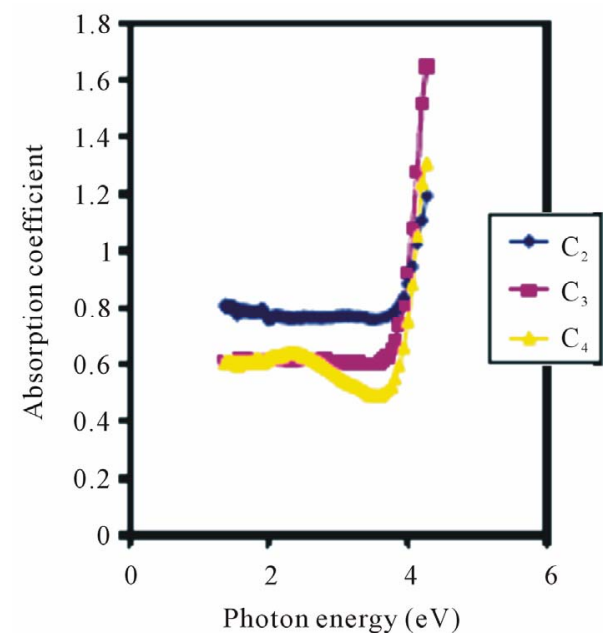

Figure 6. Absorption coefficient vs. photon energy for $\mathrm{ZnO}$ at different conc.

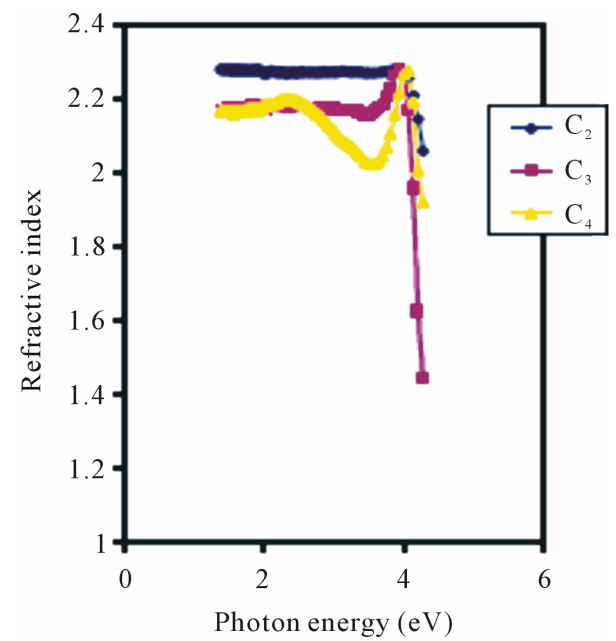

Figure 7. Refractive index vs. photon energy for $\mathrm{ZnO}$ thin films at different conc. 


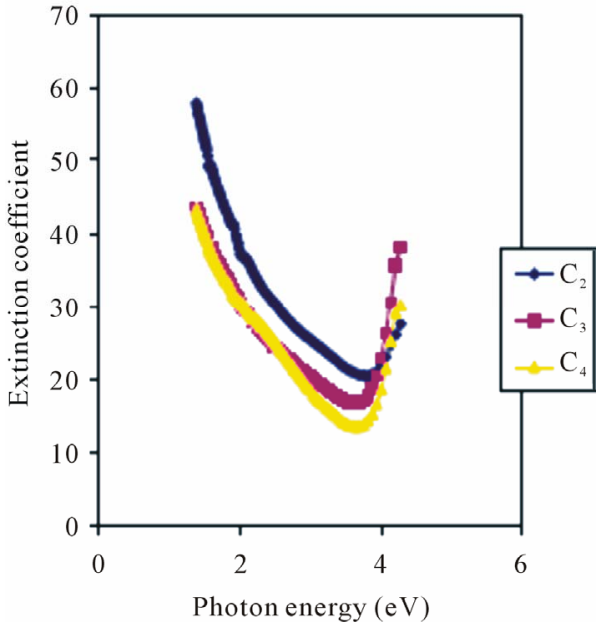

Figure 8. Extinction coefficient vs. photon energy for $\mathrm{ZnO}$ thin films at different conc.

However, the $0.05 \mathrm{M}$ concentration has the lowest extinction coefficient of about $13.93 \times 10^{-3}$ in the ultraviolet region. In general all the concentrations have the lowest value of extinction coefficient in the higher energy region (between $3 \mathrm{eV}$ and $4 \mathrm{eV}$ ) and the maximum value in the low energy region (between $1 \mathrm{eV}$ and $2 \mathrm{eV}$ ). Low and high values of extinction coefficient at high and low energy regions respectively have been reported [26].

The band gap increases with concentration as shown in Figure 9. The average band gap for the $0.025 \mathrm{M}, 0.05 \mathrm{M}$ and $0.1 \mathrm{M}$ concentrations are $1.16 \mathrm{eV}, 1.22 \mathrm{eV}$ and 1.4 $\mathrm{eV}$ respectively.

These values are lower than the direct band gaps of $\mathrm{ZnO}$ films deposited by Chemical Bath method [26] which lie between $1.60 \mathrm{eV}$ and $1.80 \mathrm{eV}$.

Our values are also far lower than $3.29 \mathrm{eV}$ band gap obtained for aluminium doped $\mathrm{ZnO}$ deposited using radio frequency (r.f) megnetron sputtering [18], and intrinsic band gap of $3.20 \mathrm{eV}$ for $\mathrm{ZnO}$ films deposited by spray pyrolysis [29]. The low values of the direct band gap obtained indicate that the $\mathrm{ZnO}$ thin film materials prepared by ACG method are suitable for use as absorber layers in solar cells. The low values of the band gaps obtained in this work may be due to preparation conditions Ezema et al. [26].

Real dielectric constant increases with concentration in the visible region as shown in Figure 10. The $0.025 \mathrm{M}$, $0.05 \mathrm{M}$ and $0.1 \mathrm{M}$ concentrations have average real dielectric constants of $4.76,4.85$ and 5.15 respectively in the visible region of the electromagnetic spectrum.

However, the $0.05 \mathrm{M}$ concentration has the lowest real dielectric constant of about 4.09 in the ultra-violet region. Figure 11 is the Imaginary dielectric constant that increases with concentration in the visible range.

The $0.1 \mathrm{M}, 0.05 \mathrm{M}$ and $0.025 \mathrm{M}$ concentrations have average values of imaginary dielectric constant which

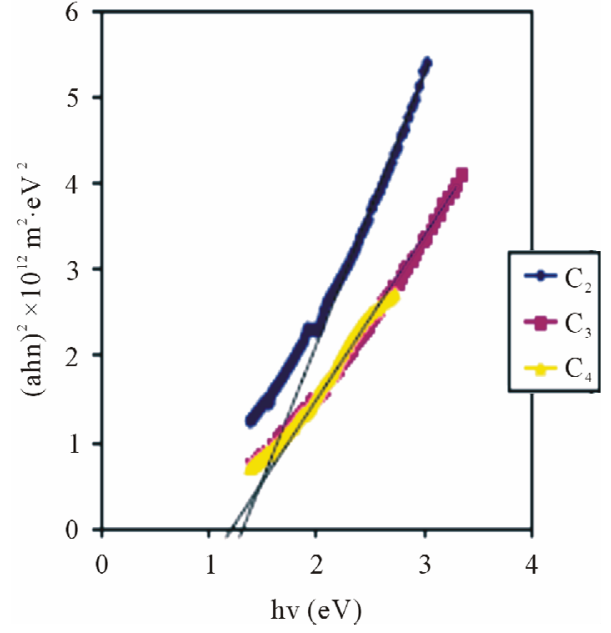

Figure 9. Direct band gap plot for $\mathrm{ZnO}$ thin films at different conc.

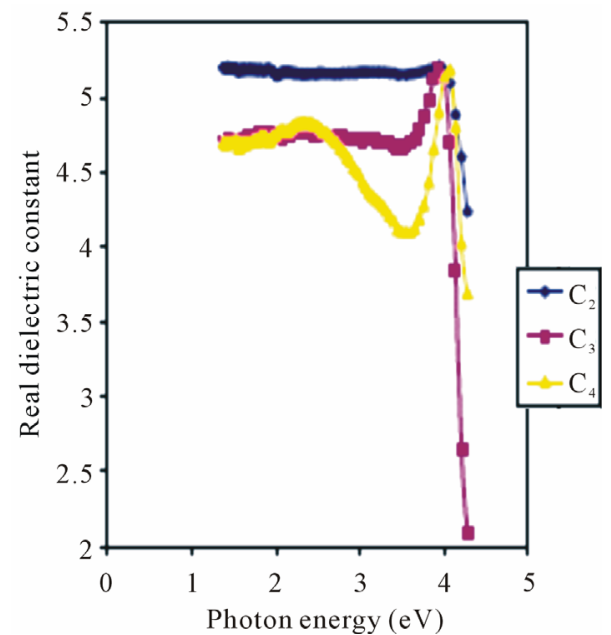

Figure 10. Real dielectric constant vs. photon energy for ZnO thin films at different conc.

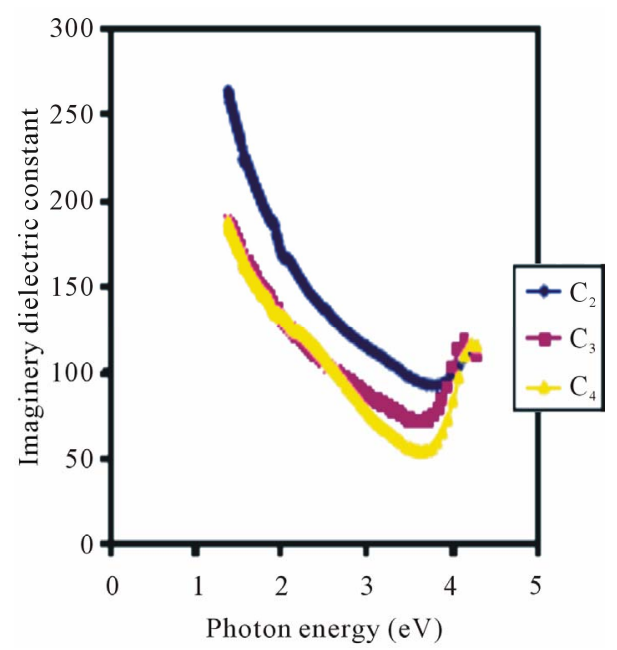

Figure 11. Imaginery dielectric constant vs. photon energy for $\mathrm{ZnO}$ thin films at different conc. 
ranges from $180.3 \times 10^{-3}$ for $2 \mathrm{eV}$ to $118.18 \times 10^{-3}$ for 3 $\mathrm{eV}, 143.93 \times 10^{-3}$ for $2 \mathrm{eV}$ to $78.785 \times 10^{-3}$ for $3 \mathrm{eV}$ and $143.93 \times 10^{-3}$ for $2 \mathrm{eV}$ to $89.39 \times 10^{-3}$ for $3 \mathrm{eV}$ respectively. This shows that the imaginary dielectric constant decreases with increasing photon energy (decreasing wavelength) for all concentrations in the visible region.

However, the $0.05 \mathrm{M}$ concentration has the lowest imaginary dielectric constant of about 56.06 in the ultra violet region. All concentrations have their lowest imaginary dielectric constant values in the ultra-violet region.

The photomicrographs as shown in Figure 12 indicate uniform deposition of the $\mathrm{ZnO}$ thin films on the glass substrate. While $\mathrm{C}_{2}$ and $\mathrm{C}_{3}$ show stretches of rod $\mathrm{C}_{4}$ shows clusters of thin films on the substrates.

\section{Conclusions}

Crystals of $\mathrm{ZnO}$ have been successfully grown on glass
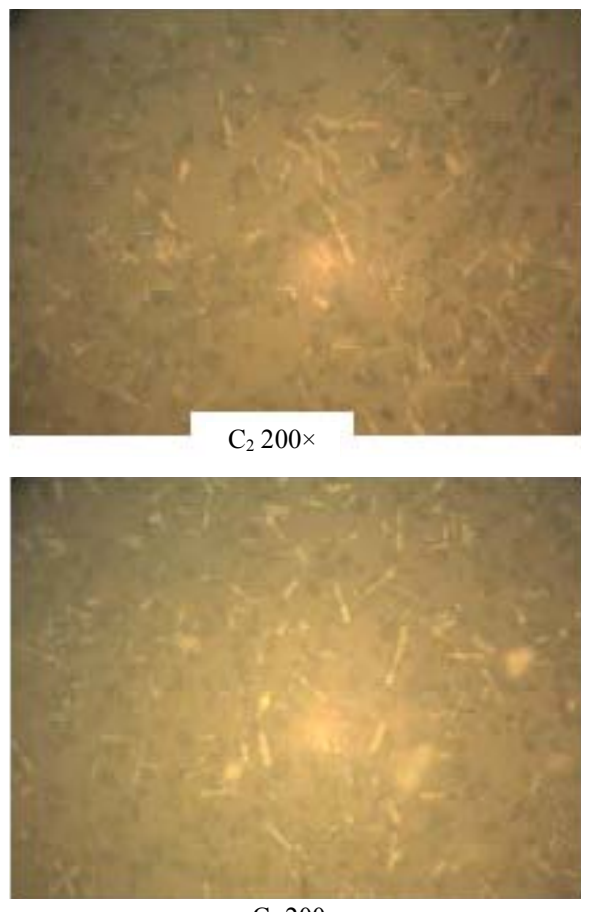

$\mathrm{C}_{3} 200 \times$

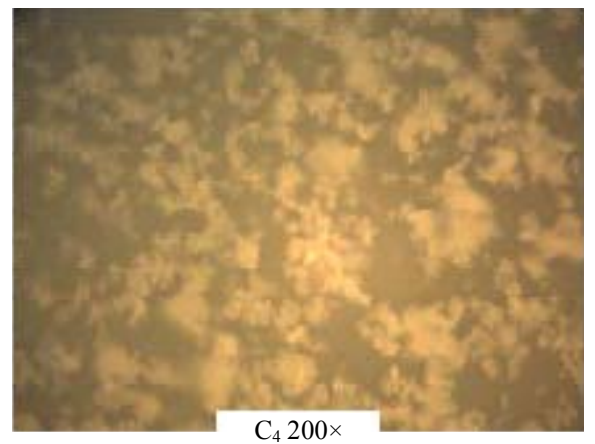

Figure 12. Photomicrographs of ACG ZnO thin films. slides in the form of thin films from the aqueous solution of hexahydrated zinc nitrate and hexamine after the fashion of Lionel Vassieres [47]. The concentration of the precursors was found to vary directly with absorbance, reflectance, absorption coefficient, extinction coefficient, refractive index, direct band gap, real dielectric constant and imaginary dielectric constant. The transmittance of the thin films was found to vary inversely with the concentration of the precursors.

The results indicate the suitability of $\mathrm{ZnO}$ thin films prepared by the Aqueous Chemical Growth method for various optoelectronic applications such as absorber layer in solar cells.

\section{REFERENCES}

[1] T. Kiyoshi, Y. Akihiko and S. Adarsh, "Wide Bandgap Semiconductors: Fundamental Properties and Modern Photonic and Electronic Devices," Springer, Heidelberg, 2007, p. 257.

[2] C. Klingshirn, "ZnO: Material, Physics and Applications," Physical Chemistry, Vol. 8, No. 6, 2007, pp. 782-803. doi:10.1002/cphc. 200700002

[3] E. Wiberg and A. F. Holleman, "Inorganic Chemistry," Elsevier, Amsterdam, 2001.

[4] J. W. Nicholson, Journal of Materials Science, Vol. 33, No. 225, 1998.

[5] J. L. Ferracane, "Material in Dentistry: Principles and Application," Lippincott Williams \& Wilkins, Philadelphia, 2001.

[6] C. K. Park, M. R. Silsbee and D. M. Roy, "Setting Reaction and Resultant Structure of Zinc Phosphate Cement in Various Orthophosphoric Acid Cement-Forming Liquids," Cement and Concrete Research, Vol. 28 No. 1, 1998, pp. 141-150. doi:10.1016/S0008-8846(97)00223-8

[7] N. N. Greenwood and A. Earnshaw, "Chemistry of the Elements," Butterworth-Heinemann, Oxford, 1997.

[8] U. Özgür, Y. T. Alivov, C. Liu, A. Teke, M. A. Reshchikov, S. Doğan, V. Avrutin, S. J. Cho, et al., "A Comprehensive Review of ZnO Materials and Devices," Journal of Applied Physics, Vol. 98, No. 4, 2005, Article ID: 041401.

[9] S. Baruah and J. Dutta, "Hydrothermal Growth of $\mathrm{ZnO}$ Nanostructures," Science and Technology of Advanced Materials, Vol. 10, No. 1, 2009, Article ID: 013001.

[10] U. Rossler, "Landolt-Bornstein, New Series, Group III," Springer, Heidelberg, 1999.

[11] T. Mahalingam, V. S. John, M. Raja, Y. K. So and P. J. Sabastian, "Electrodeposition and Characterization of Transparent ZnO Thin Films," Solar Energy Materials and Solar Cells, Vol. 88, No. 2, 2005, pp. 227-235.

[12] Y. R. Shinde, T. P. Gujar, C. D. Lokhande, R. S. Nane and S. H. Han, Materials Chemistry and Physics, Vol. 326, 2006.

[13] A. E. Ajuba, S. C. Ezugwu, P. U. Asogwu and F. I. Ezema, Chalcogenide Letter, Vol. 10, 2010, pp. 573-579.

[14] T. Soki, Y. Hatanaka and D. C. Look, "ZnO Diode Fab- 
ricated by Excimer-Laser Doping," Applied Physics Letters, Vol. 76, No. 22, 2000, pp. 3257-3259.

[15] Y. Lin. C. R. Gorla, S. Linng, N. Emanetoglu, Y. Tor, H. Shen and M. Wraback, 'Ultraviolet Detectors Based on Epitaxial ZnO Films Grown by MOCVD," Journal of Electronic Materials, Vol. 29, No. 1, 2000, pp. 69-74.

[16] V. R. Shinde, T. P. Gujar and C. D. Lokhande, "LPG Sensing Properties of ZnO Films Prepared by Spray Pyrolysis Method: Effect of Molarity of Precursor Solution," Sensors and Actuators H, Vol. 120, No. 2, 2007, pp. 551-559.

[17] A. Ennaoui, S. Siebentrith, M. Ch. Lux-Steiner, W. Riedl and F. Karg, "High-Efficiency Cd-Free CIGSS Thin-Film Solar Cells with Solution Grown Zinc Compound Buffer Layers," Solar Energy Materials and Solar Cells, Vol. 67, No. 1-4, 2002, pp. 31-40.

[18] Y. Chen, D. Bagnall and T. Yao, "ZnO as a Novel Photonic Material for the UV Region," Materials Science and Engineering B, Vol. 75, No. 2-3, 2000, pp. 190-198.

[19] S. Liang, H. Sheng, Y. Liu, Z. Hio, Y. Lu and H. Shen, Journal of Crystal Growth, Vol. 225, No. 110, 2001.

[20] M. H. Koch, P. Y. Timbrell and R. N. Lamb, "The Influence of Film Crystallinity on the Coupling Efficiency of ZnO Optical Modulator Waveguides," Semiconductor Science and Technology, Vol. 10, No. 11, 1995, p. 1523.

[21] C. R. Gorla, N. W. Emanetoglu, S. Liang, W. E. Mayo, K. Lu, M. Wraback and H. Shen, "Structural, Optical, and Surface Acoustic Wave Properties of Epitaxial ZnO Films Grown on (012) Sapphire by Metalorganic Chemical Vapor Deposition," Journal of Applied Physics, Vol. 85, No. 5, 1999, pp. 2595-2603.

[22] V. R. Shinde, C. D. Lokhande, R. S. Mane and S. H. Han, "Hydrophobic and Textured ZnO Films Deposited by Chemical Bath Deposition: Annealing Effect," Applied Surface Science, Vol. 245, No. 1-4, 2005, pp. 407-413.

[23] A. Ennaoui, M. Weber, R. Scheer and H. J. Lewerenz, "Chemical-Bath ZnO Buffer Layer for CuInS 2 Thin-Film Solar Cells," Solar Energy Materials and Solar Cells, Vol. 54, No. 1-4, 1998, pp. 277-286.

[24] D. S. Boyle, K. Governder and P. O'Brien, Chemical Communications, Vol. 1, No. 80, 2002, p. 23.

[25] M. Ortega-Lope, A. Avila-Gaecia, M. L. Albor-Aguitera and V. M. Sankez Resendiz, "Improved Efficiency of the Chemical Bath Deposition Method during Growth of $\mathrm{ZnO}$ Thin Films," Materials Research Bulletin, Vol. 38, No. 4, 2003, pp. 1241-1248.

[26] F. I. Ezema, Journal of Research (Science), Vol. 15, No. 4, 2004, pp. 343-350.

[27] V. R. Shinde, T. P. Gujar and C. D. Lokhande, "Studies on Growth of ZnO Thin Films by a Novel Chemical Method," Solar Energy Materials and Solar Cells, Vol. 91, No. 12, 1961, pp. 1055-1061.

[28] A. Jimenez Gonzalez and R. Suarez-Para, "Effect of Heat Treatment on the Properties of $\mathrm{ZnO}$ Thin Films Prepared by Successive Ion Layer Adsorption and Reaction (SILAR)," Journal of Crystal Growth, Vol. 167, No. 3-4, 1996, pp. 649-655.

[29] M. L. de la Olvera, A. Maldonado, R. Asomoza and M.
Melendez-Lira, "Effect of the Substrate Temperature and Acidity of the Spray Solution on the Physical Properties of F-Doped ZnO Thin Films Deposited by Chemical Spray," Solar Energy Materials and Solar Cells, Vol. 71, No. 1, 2002, pp. 61-71.

[30] P. M. Izaki and T. Omi, Journal of The Electrochemical Society, Vol. 144, 1997, pp. 1949-1952.

[31] D. Gal, G. Hodes, D. Lincot and H. W. Sechock, "Electrochemical Deposition of Zinc Oxide Films from NonAqueous Solution: A New Buffer/Window Process for Thin Film Solar Cells," Thin Solid Films, Vol. 361-362, 2000, pp. 79-83.

[32] X. Hu, Y. Masuda, T. Olyi and K. Kato, "Fabrication of ZnO Nanowhiskers Array Film by Forced-Hydrolysis-Initiated-Nucleation Technique Using Various Templates," Thin Solid Films, Vol. 518, No. 2, 2009, pp. 621-624.

[33] X. Zhang, L. Wang and G. Zhow, "Synthesis of WellAligned ZnO Nanowires without Catalysts," Reviews on Advanced Materials Science, Vol. 10, 2005, pp. 69-72.

[34] S.-F. Lee, L.-Y. Lee and Y.-P. Change, Journal of Science and Engineering Technology, Vol. 5, No. 3, 2009, pp. 13-20.

[35] A. E. Ajuba, S. C. Ezugwu, B. A. Ezekoye, F. I. Ezema and P. U. Asogwa, Journal of Optoelectronics and Biomedical Materials, Vol. 2, No. 2, 2009, pp. 73-78.

[36] V. R. Shinde, C. D. Lokhande, R. S. Mane and S. H. Han, Applied Surface Science, Vol. 245, No. 407, 2005.

[37] P. Li, H. Liu, F. X. Xu and Y. Wei, "Controllable Growth of ZnO Nanowhiskers by a Simple Solution Route," Materials Chemistry and Physics, Vol. 112, No. 2, 2008, pp. 393-397.

[38] H. Zhai, W. Wu, F. Lu and H. S. Wang, "Effects of Ammonia and Cetyltrimethylammonium Bromide (CTAB) on Morphologies of $\mathrm{ZnO}$ Nanoand Micromaterials under Solvothermal Process," Material Chemistry and Physics, Vol. 112, No. 3, 2008, pp. 1024-1028.

[39] D. Yiamsawas, K. B. Savanitchakul and W. K. W. Supamonkon, Journal of Microscopy Society of Thailand, Vol. 13, No. 75, 2009.

[40] S. Y. Chu and T. M. Yan, "Characteristics of Sol-Gel Synthesis of ZnO-Based Powders," Journal of Materials Science Letters, Vol. 19, No. 4, 2000, pp. 349-352.

[41] D. Geeth and T. Tilagarathi, Digest Journal of Nanomaterials and Biostructures, Vol. 5, No. 1, 2010, p. 297301.

[42] C. Gumus, O. M. Ozkendir, H. Kavak and Y. Ufuktepe, Journal of Optoelectronics and Advanced Materials, Vol. 8, No. 1, 2006, pp. 299-303.

[43] C. Cruz-Vázquez, F. Rocha-Alonzo, S. E. Burruel-Ibarra, M. Inoue and R. Bernal, "Fabrication and Characterization of Sulfur Doped Zinc Oxide Thin Films," Superficies y Vacio, Vol. 13, 2001, pp. 89-91.

[44] A. Sachez-Juarez, A. Tiburcio-Silver and A. Ortiz, Solar energy Materials and Solar Cells, Vol. 52, No. 3-4, 1998, pp. 301-311. doi:10.1016/S0927-0248(97)00246-8

[45] P. Pushparajah, A. K. Arof and S. Radhakrishna, "Physical Properties of Spray Pyrolysed Pure and Doped ZnO Thin Films," Journal of Physics D: Applied Physics, Vol. 
27 , No. 7,1994 , pp. $1518-1521$. doi:10.1088/0022-3727/27/7/027

[46] A. E. Jimenez Gonzalex and J. A. Soto Urueta, "Optical Transmittance and Photoconductivity Studies on $\mathrm{ZnO}: \mathrm{Al}$ Thin Films Prepared by the Sol-Gel Technique," Solar En- ergy Materials and Solar Cells, Vol. 52, No. 3-4, 1998, pp. 345-353. doi:10.1016/S0927-0248(97)00243-2

[47] L. Vayssieres, "On the Design of Advanced Metal Oxide Nanomaterials," International Journal of Nanotechnology, Vol. 1, No. 1-2, 2004, pp. 1-41. 